\title{
The Role of Transcription Factors in Cytokine-Mediated Apoptosis of Lymphocytes
}

\author{
Olga Evgenevna Saveleva \\ Siberian State Medical University \\ 2 Moscowski Trakt, Tomsk 634050, Russia \\ Tel: 7-905-089-2137 E-mail: olga_chechina@mail.ru \\ Larisa Sergeevna Litvinova (Corresponding author) \\ Baltic Federal University of Immanuel Kant \\ 14 Nevskogo Street, Kaliningrad 236041, Russia
}

Tel: 7-911-48-20-489 E-mail: larisalitvinova@yandex.ru

Evgeniya Sergeevna Anishchenko

Baltic Federal University of Immanuel Kant

14 Nevskogo Street, Kaliningrad 236041, Russia

Tel: 7-9062-34-35-30 E-mail: anishchenkoea@gmail.com

Viacheslav Viktorovish Novitsky

Siberian State Medical University

2 Moscowski Trakt, Tomsk 634050, Russia

Tel: 7-38222-590559Ｅ-mail: office@ssmu.ru

Nataliya Vladimirovna Riazantseva

Siberian State Medical University

2 Moscowski Trakt, Tomsk 634050, Russia

Tel: 7-913-8535659 E-mail: nv_ryazan@mail.ru

Received: November 21, 2011

doi:10.5539/ijb.v4n1p129
Accepted: December 2, 2011 Published: January 1, 2012

URL: http://dx.doi.org/10.5539/ijb.v4n1p129

This work was financially supported by the Federal Target Program "Research and development on priority directions of scientific-technological complex of Russia for 2007-2012" (GC № 16.512.11.2087), "Scientific-pedagogical personnel of innovative Russia on 2009-2013" (GC № 16.740.11.0360, GC № 16.740.11.0636)

\begin{abstract}
The role of transcription factors in the implementation of IL-2 and IL-4 proapoptotic effects investigated in the in vitro experiment. It is shown that recombinant IL-2 at a dose of $0.10 \mathrm{ng} / \mathrm{ml}$ and IL-4 at a dose of $0.15 \mathrm{ng} / \mathrm{ml}$ have apoptotic effects on lymphocytes. At the apoptosis induction by rIL-2 and rIL-4 the transcription factors $\mathrm{NF}-\mathrm{kB}, \mathrm{p} 53, \mathrm{pRb}$ and inhibitor of cyclin-dependent kinases $\mathrm{p} 21^{\mathrm{WAF} 1 / \mathrm{CIP} 1}$ are activated.
\end{abstract}

Keywords: Apoptosis, Cytokines, NF-kB, p53, pRb, p21 ${ }^{\mathrm{WAF} 1 / \mathrm{Cip} 1}$, Lymphocytes 


\section{Introduction}

Apoptosis as a form of cells death plays an important role in human pathology. Disorder of the programmed cells death realization leads to various diseases associated with increasing or conversely inhibition of apoptosis (Elmore S., 2007). Hormones, cytokines, various xenobiotics and genetic features of the cell are a variety of external and internal factors governing the running of apoptosis. (Belushkina N.N., Severin S.E., 2001; Elmore S., 2007).

Cytokines are the most numerous group of biologically active substances, whose influence on the process of immune cells apoptosis is being intensively studied. A large group of cytokines (IL-3, IL-12, growth factors) that trigger endogenous protection program of cells from apoptosis is revealed. A number of other cytokines (TNFa, IL-1, -5, etc.), by contrast, has the ability to induce apoptosis (Belushkina N.N., Severin S.E., 2001). However, there is evidence that cytokines has a dual effect on apoptosis. There are IFN- $\gamma$, IL-2, IL-4, IL-10 and others (Wilke C.M. et al., 2011).

The effect exerted to a cell by cytokine, is determined by the dose. We have previously obtained results the dose-dependent effect of TNF $\alpha$ on apoptosis (Ryazantseva N.V., et al., 2010). The cytokine action also depends on the type of target cells. Thus, IL-12 induces apoptosis in NK cells, IL-4 and IL-10 - monocytes, IL-10 T-lymphocytes. IFN- $\alpha$ induces apoptosis of bone marrow cells. After the IFN action through the TCR the apoptosis of effector cells increases (Belushkina N.N., Severin S.E., 2001). In addition, the effect of cytokines depends on the functional status of cells (the degree of differentiation, functional activity, the state of the receptor apparatus). Thus, IFN- $\gamma$ exerts a selective effect on virus infected cells, because in this case it reduces the level of transcription factor NF-kB activity and thereby contributes to their apoptotic death, simultaneously inhibits the presentation of TRAIL-R1 and TRAIL-2 on the surface of the adjacent uninfected cells, promoting their survival (Hoskin D.W., 2000). In recent years, there is evidence that the stimulating factors (such insulin and epidermal growth factor) action to activated T-cells, the Fas-mediated apoptosis is canceled. The basis for this phenomenon is the mechanism of apoptosis inhibitors protein activation and inhibition of caspase activation (Reed J.C. et al., 2000; Elmore S., 2007).

One of the leading roles in the regulation of the cells survival and apoptosis belongs to the transcription factors. P53 plays an important role in maintaining the genome integrity and stability by elimination cells with the DNA damage of different nature. NF-kB is a universal transcription factor that controls immune response, apoptosis and cell cycle genes expression. Proteins $\mathrm{pRb}$ and $\mathrm{p} 21^{\mathrm{WAF} 1 / \mathrm{Cip} 1}$ are regulators of the cell cycle. These proteins may cause cell cycle arrest, followed by the apoptosis induction (Fridman J.S., Lowe S.W., 2003; Kucharczak J. et al., 2003; Garner E. et al., 2007; Schonn I. et al., 2010).

Despite active investigation of the individual cytokines role in apoptosis, the molecular mechanisms of its regulation remain unknown (Elmore S., 2007). The data about the role of NF-kB, p53, pRb, and p21 ${ }^{\mathrm{WAF} 1 / \mathrm{Cip} 1}$ in cytokine-induced apoptosis are highly fragmented. For example, the experiments carried out on different cell lines demonstrated that the apoptosis action under TNF $\alpha$ influence is accompanied by preferential activation one of the transcription factor NF-kB or p53 (Fridman J.S., Lowe S.W., 2003; Kucharczak J. et al., 2003) and undetermined involvement of $\mathrm{p} 21^{\mathrm{WAF} 1 / \mathrm{Cip} 1}$ in the TNF $\alpha$-induced cell death (Webster G.A., Perkins N.D., 1999; Schonn I. et al., 2010).

This issue is devoted to studyof molecular mechanisms, associated with cytokines and cellular reaction to the response of cytokines (Yarilin A.A., 1997; Wilke C.M. et al., 2011). The aim of this study is to evaluate the involvement of transcription factors NF-kB, p53 and pRb, as well as an inhibitor of cyclin-dependent kinases $\mathrm{p} 21^{\mathrm{WAF} 1 / \mathrm{Cip} 1}$ in IL-2 and IL-4 induced apoptosis of lymphocytes.

\section{Materials and Methods}

\subsection{The biological material collection and lymphocytes extraction}

The isolated venous blood lymphocytes of 22 healthy donors (12 men and 10 women aged 22-30 years) was used in the in vitro experiment.

Lymphocytes were isolated under sterile conditions from whole venous blood by gradient centrifugation. Venous heparinized blood $(25 \mathrm{U} / \mathrm{ml})$ was heated at $37{ }^{\circ} \mathrm{C}$ for $40-60 \mathrm{~min}$ to plasma and erythrocytes separation. Plasma layered on density gradient Ficoll-Paque («Pharmacia», Sweden) $\left(\rho=1,077 \mathrm{~g} / \mathrm{cm}^{3}\right)$ in a 2:1 ratio and centrifuged at $500 \mathrm{~g}$ for $20 \mathrm{~min}$. Formed interfacial cells ring was collected in a sterile centrifuge tube, washed twice with RPMI-1640 medium («Vector-Best», Russia) for $10 \mathrm{~min}$ at $500 \mathrm{~g}$. 


\subsection{The lymphocytes cultivation}

Extracted lymphocytes standardized to $2,0 \times 10^{6} / \mathrm{ml}$. Then cultured in RPMI-1640 («Vector-Best», Russia), supplemented with rIL-2 and rIL-4 («Invitrogen», USA) at concentrations of 0,015-1,000 ng/ml and incubated for $18 \mathrm{~h}$ at $37{ }^{\circ} \mathrm{C}$ and $5 \% \mathrm{CO}_{2}$.

\subsection{The lymphocytes apoptosis evaluation}

After cultivation, cells were centrifuged $3 \mathrm{~min}$ in phosphate-buffered saline (PBS) ( $\mathrm{pH}=7.2$ ). The washed cells were resuspended in annex buffer, containing annexin V, labeled by fluorescein isothiocyanate (FITC), propidium iodide («Beckman Coulter», USA) and incubated for $15 \mathrm{~min}$ in the dark at room temperature. Analysis of samples was carried out on a flow cytometer Epics XL («Beckman Coulter», USA).

\subsection{The cells lysates preparation}

The lymphocytes in quantities of $1 \times 10^{6} / \mathrm{ml}$ were washed by PBS, centrifuging $5 \mathrm{~min}$ at $1680 \mathrm{~g}$, after cultivation. The supernatant was removed, $15 \mathrm{ml}$ of a solution containing a proteinase inhibitors («Sigma Aldrich», USA), dimethyl sulfoxide («Helicon», USA) at $1: 100,135 \mathrm{ml}$ of lysis buffer $(50 \mathrm{mM}$ Tris- $\mathrm{HCl}(\mathrm{pH}=6.5), 100 \mathrm{mM}$ dithiothreitol («Helicon», USA), 0.1\% bromophenol blue («Helicon», USA), 2\% sodium dodecyl sulfate (SDS), $15 \%$ glycerol at the temperature $4{ }^{\circ} \mathrm{C}$ («Helicon», USA)) was added and mixed thoroughly by vortex. This mixture were placed on ice for $15 \mathrm{~min}$, then cells were incubated in an incubator at $95{ }^{\circ} \mathrm{C}, 15 \mathrm{~min}$. Cooled to room temperature samples were shook by vortex for 20 seconds and then used to determine the content of the lymphocytes transcription factors.

\subsection{The content of transcription factors determined by Western blotting analysis}

The cells lysate proteins were separated by molecular weight by electrophoresis in an electric field $(10 \mathrm{~V} / \mathrm{cm}$ path) at 5\% and 10\% SDS-PAGE. The protein molecular weight markers (14.3-220.0 kDa, «Fermentas», EU) were used. Then, proteins were transferred to the nitrocellulose membrane («Bio-Rad», USA). Next, membranes were incubated sequentially in $0.05 \%$ TTBS, pH $7.4(20 \mathrm{mM}$ Tris- $\mathrm{HCl}, 150 \mathrm{mM} \mathrm{NaCl}$ and $0.05 \%$ Tween-20) with $5 \%$ non fat dry milk with primary antibodies to subunit RelA NF-kB (p65), p53 non phosphorylated, pRb and $\mathrm{p} 21^{\mathrm{WAF} 1 / \mathrm{Cip} 1}$ («Sigma Aldrich», USA). Then the labelled by peroxidase secondary antibodies («Biosource», Belgium) and the substratebased tetramethylbenzidine were applied to the membrane. The conclusion about the content of the tested antigen in cell was based on a signal relative to the value of the desired protein signal from the enzyme glyceraldehyde 3-phosphate dehydrogenase (G3PDH) («Chemicon», USA). The results were expressed in standard units.

\subsection{Statistical analysis}

Analysis of the data was carried out using SPSS software, version 17.0 (SPSS, Chicago, IL). The median (Me) of the first and third quartiles (Q1-Q3) was calculated for each analyted index. The non-parametric U-Mann-Whitney test was used to determine the reliability of differences between independent groups. Differences were considered as significant (significance level is $\mathrm{P}<0.05$ ).

\section{Results}

Recent study in vitro showed that rIL-2 and rIL-4 (from the concentration of $0.10 \mathrm{ng} / \mathrm{ml}$ and $0.15 \mathrm{ng} / \mathrm{ml}$, respectively) induce apoptosis of lymphocytes. Further dosage increasing of cytokines was associated with the number of apoptotic lymphocytes increasing (Figure 1,2). The rIL-2 effects on cells in a dose of $0.10 \mathrm{ng} / \mathrm{ml}$ resulted to the transcription factor NF-kB $(\mathrm{P}<0.05)$ content increasing in comparison with a similar intact blood lymphocyte culture. The content of NF-kB also increased as compared with intact cells, with apoptosis-inducing concentration of rIL-4 addition to the incubation medium, although to a lesser extent than with rIL-2 influence (Figure 3). The analysis of intracellular p53 level showed that its quantity had been reducing $(\mathrm{P}<0.05)$ in response to pro apoptotic doses of rIL-2 in lymphocytes. The same trend was typical for cells subjected to 0.15 $\mathrm{ng} / \mathrm{ml} \mathrm{rIL-4} \mathrm{influence} \mathrm{(Figure} \mathrm{3).} \mathrm{Lymphocytes} \mathrm{incubation} \mathrm{with} \mathrm{apoptosis-inducing} \mathrm{doses} \mathrm{of} \mathrm{rIL-2} \mathrm{and} \mathrm{rIL-4}$ caused the appearance of another transcription factor $\mathrm{pRb}$ in the cells $(\mathrm{P}<0.05)$, while in the culture of intact cells this protein was absent (Figure 4). Analysis of the intracellular level of cyclin-dependent kinases inhibitor $\mathrm{p}^{21 \mathrm{WAF} / \mathrm{Cip} 1}$, showed that in response to apoptotic doses of both rIL-2 and rIL-4 the protein quantity in lymphocytes increased compared with intact cells, although it did not reach statistically significant level (Figure 4).

\section{Discussion}

Transcription factor NF-kB has a key role in the cell proliferation and programmed cell death regulation (Kucharczak J. et al., 2003). In an attempted experiment it was found that the effect of rIL-2 and rIL-4 on 
lymphocytes accompanied by an increased content of free RelA NF-kB subunit (Figure 3). The NF-kB activation is mediated by the JNK class of MAP kinases. Redox-sensitive JNK are participating in the cytokine-induced apoptosis and the effect on the kinase dependent phosphorylation inhibitor of NF-kB is to lead to the release of the active form of the transcription factor (Rivas M.A. et al., 2008; Chasovskikh N.J., et al., 2009). NF-kB binds to specific kB-DNA sites, after translocation into the nucleus and activates transcription of various target genes (Kucharczak J. et al., 2003). Transcription factor p53 has an extremely high value for normal cellular functioning. Activation of $\mathrm{p} 53$ in response to various stress factors and cell damage occurs by the formation of the phosphorylated form (Liu B. et al., 2008). Obviously, denoted non phosphorylated p53 decreasing content in cultured with rIL-2 and rIL-4 lymphocytes, as compared with intact cells (Figure 3) shows an intensification of the active form of 53 formation, which may be due to stimulation of the reactive oxygen synthesis that contribute to the phosphorylation of p53 (Liu B. et al., 2008; Ryazantseva N.V., et al., 2008).

The most important regulation tool of apoptosis is quantity control of proteins belonging to the family Bcl-2 through the protein p53 in the cell. (Fridman J.S., Lowe S.W., 2003, Chechina O.E., et al., 2011). As the tumor suppressor p53 determines the maintenance of cell and tissue homeostasis in the body. The p53 arrests the cell cycle during DNA repair, and includes the programs of apoptosis and senesens at genotoxic stress (Fridman J.S., Lowe S.W., 2003).

There are several ways of non phosphorylated p53 utilization, associated with its phosphorylation, ubiquitination, acetylation and methylation (Liu B. et al., 2008). Therefore, to evaluate the transition of p53 in its active state it was necessary to investigate the change of a protein amount, which gene is controlled by p53. The protein $\mathrm{p} 21^{\mathrm{WAF} 1 / \mathrm{Cip} 1}$ satisfies the mentioned requirements. This protein belongs to Cip1/Kip1-cell cycle regulators protein family (Garner E. et al., 2007).

The observed increase in the amount of protein in lymphocytes under the influence of recombinant cytokines, as compared with intact cells (Figure 4), appear to suggest that registered reducing of the non phosphorylated p53 quantity in response to the apoptogenic effect of rIL-2 and rIL-4 is a consequence of its phosphorylation. In addition, the protein $\mathrm{p} 21^{\mathrm{WAF} 1 / \mathrm{Cipl}}$ quantity changing in cytokine-induced apoptosis is an important indicator of the protein involvement in cell death (Webster G.A., Perkins N.D., 1999).

The protein $\mathrm{p} 21^{\mathrm{WAF} 1 / \mathrm{Cip} 1}$ selectively inhibits the activity of cyclin D1/CDk4- and cyclin E/CDk2-complexes that leads to cell cycle arrest in G1 phase. The main substrate of cyclin D-Cdk4 and cyclin D-Cdk6 complexes is tumor suppressor $\mathrm{pRb}$, which regulates cell entry into the cell cycle (Garner E. et al., 2007). In this regard, we assessed the content of $\mathrm{pRb}$ and identified its appearance in lymphocytes under the rIL-2 and rIL-4 action (Figure 4).

In non dividing and proliferating cells, the $\mathrm{pRb}$ and its homologs do not phosphorylated in early G1-phase. In this state, they bind and block the transcription complexes E2F-DP which regulate the activity of several genes. The products of these genes are necessary for the initiation and passage of S-phase. The protein family of E2F binding with $\mathrm{pRb}$ inhibits its transcriptional activity. The mitogenic signals induced by growth factors are associated with $\mathrm{pRb}$ phosphorylation in the middle of G1-phase by the cyclin D-Cdk4 (or cyclin D-Cdk6) complex, which causes the release of transcription factor E2F-DP from the complex with $\mathrm{pRb}$ and its activation. One of this phenomenon's consequences is the stimulation of the cyclin E gene transcription and as a result activated complexes cyclin E-Cdk2, also phosphorylating the $\mathrm{pRb}$. Thus a regulatory loop forms that supports the activity of transcription factor E2F-DP and their controlling genes that support the DNA replication. After S-phase completion the pRb turns into dephosphorylated state in which it blocks the E2F-DP activity and input into the next S-phase (for its initiation necessary a new mitogenic stimulus, which may activate the complexes of cyclin D-Cdk4, -6) (Garner E. et al., 2007; Schonn I. et al., 2010).

Thus, the study showed that the cultivation of lymphocytes in medium containing rIL-2 and rIL-4, lead to increase of the NF-kB content, appearance of the protein $\mathrm{pRb}$ in cells, as well as to reduce non phosphorylated forms of $\mathrm{p} 53$. Probably because these proteins in the signal comes from the cytokine receptor is determined by the difference between life or death of cells by running the irreversible stages of apoptosis.

\section{References}

Belushkina N. N. \& Severin S. E. (2001). The molecular basis of apoptosis pathology. Archive of Pathology, 1, 51-60.

Chasovskikh N. Y., Ryazantseva N. V., Kaygorodova E. V., et al. (2009). The state of MAP-kinases JNK system and p38 in mononuclear leukocytes in inflammation. Medical Immunology, 11 (6), 515-522.

Chechina O. E., Ryazantseva N. V., Novitsky V. V., et al. (2011). The proteins of Bcl-2 family are molecular 
targets of IL-2 and IL-4 apoptotic effects. Immunology, 32 (3), 127-130.

Elmore S. (2007). Apoptosis: A review of programmed cell death. Toxicol Pathol., 35(4), 495-516. http://dx.doi.org/10.1080/01926230701320337

Fridman J. S., Lowe S.W. (2003). Control of apoptosis by p53. Oncogene, 22, 9030-9040. http://dx.doi.org/10.1038/sj.onc.1207116

Garner E., Martinon F., Tschopp J. et al. (2007). Cells with Defective p53-p21-pRb Pathway Are Susceptible to Apoptosis Induced by p84N5 via Caspase-6. Cancer Res, 67(16), 7631-7637. http://dx.doi.org/10.1158/0008-5472.CAN-07-0334

Hoskin D.W. (2000). Trail: a newly described effector mechanism of cytotoxic lymphocytes. Mod Asp Immunobiol, 164(2), 136-139.

Kucharczak J., Simmons M. J., Fan Y. et al. (2003). To be, or not to be: NF-kB is the answer - role of Rel/NF-kB in the regulation of apoptosis. Oncogene, 22, 8961-8982. http://dx.doi.org/10.1038/sj.onc.1207230

Liu B., Chen Y. \& Clair D. K. St. (2008). ROS and P53: versatile partnership. Free Radic. Biol. Med., 44, 1529-1535. http://dx.doi.org/10.1016/j.freeradbiomed.2008.01.011

Reed J. C., Cardone M. H., Roy N. et al. (2000). Caspase phosphorylation, cell death, and species variability. Science, 287, 1363-1370. http://dx.doi.org/10.1126/science.287.5457.1363a

Rivas M. A., Carnevale R. P., Projetti C. J. et al. (2008). TNF alpha acting of TNFR1 promotes breast cancer growth via p42/p44 MAPK, JNK, Akt and NF-kappa B-dependent pathways. Exp. Cell. Res., 314 (3), 509-529. http://dx.doi.org/10.1016/j.yexcr.2007.10.005

Ryazantseva N. V., Novitsky V. V., Chasovskikh N. Y., et al. (2008). Redox-dependent regulation of apoptosis: the adaptive role of apoptosis active forms by oxidative stress. Russian physiological journal of Sechenov IM, 94(6), 710-718. http://dx.doi.org/10.1007/s10517-010-0873-8

Ryazantseva N. V., Novitsky V. V., Zhukova O. B., et al. (2010). The role of NF-kB, p53 and p21 in the regulation of lymphocytes TNF-alpha-mediated apoptosis. Bulletin of Experimental Biology and Medicine, 149 (1), 56-59.

Schonn I., Hennesen J. \& Dartsch D. C. (2010). Cellular responses to etoposide: cell death despite cell cycle arrest and repair of DNA damage. Apoptosis, 15(2), 162-172. http://dx.doi.org/10.1007/s10495-009-0440-9

Webster G. A. \& Perkins N. D. (1999). Transcriptional cross talk between NF-kB and p53. Mol. Cell. Biol, 19(5), 3485-3495.

Wilke C. M., Wei S., Wang L. et al. (2011). Dual biological effects of the cytokines interleukin-10 and interferon- $\gamma$. Cancer Immunol Immunother., 60 (11), 1529-1541._http://dx.doi.org/10.1007/s00262-011-1104-5

Yarilin A. A. (1997). The cytokines system and principles of its functioning in health and disease. Immunology, 5, $7-14$. 


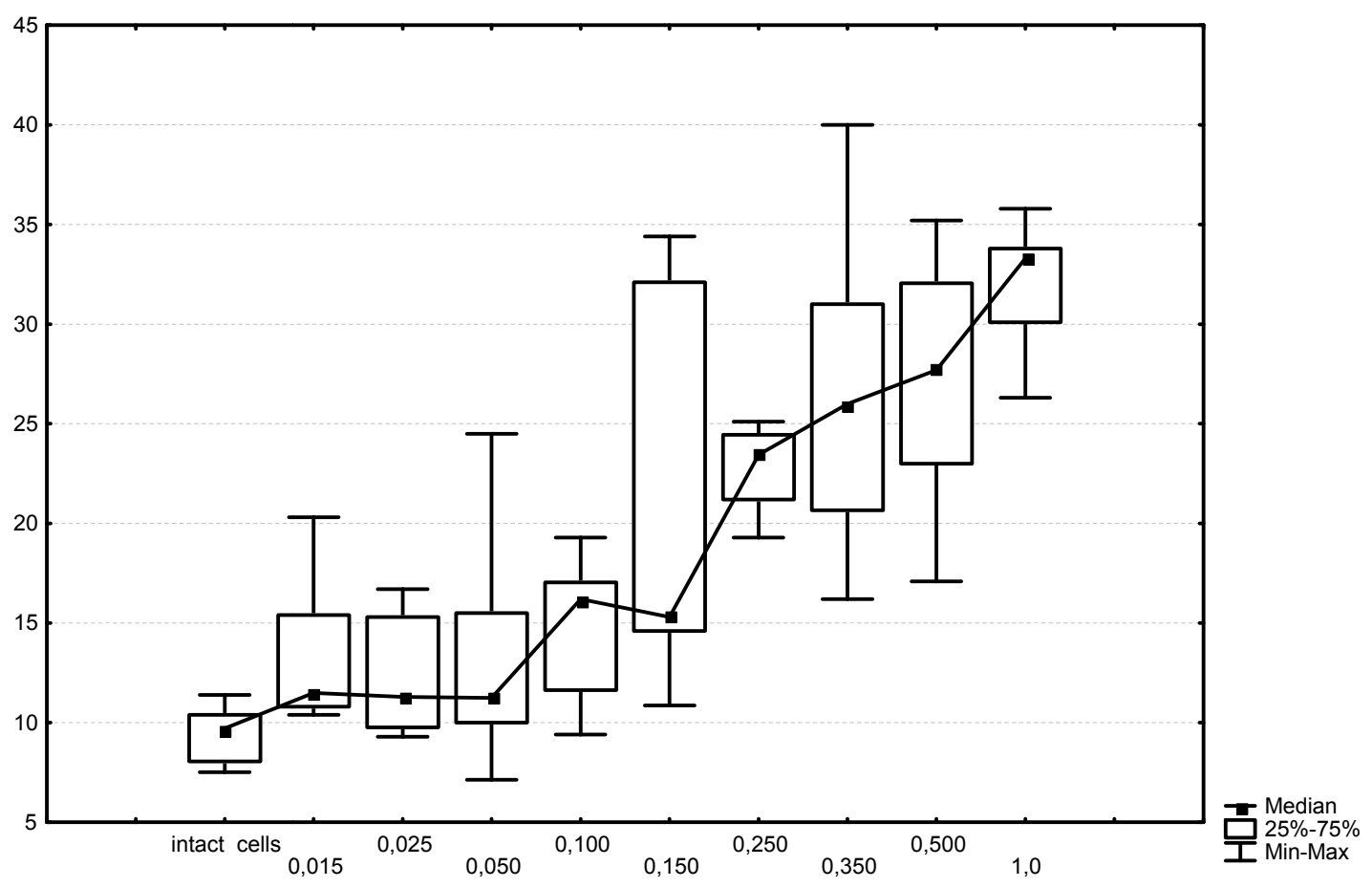

(A)

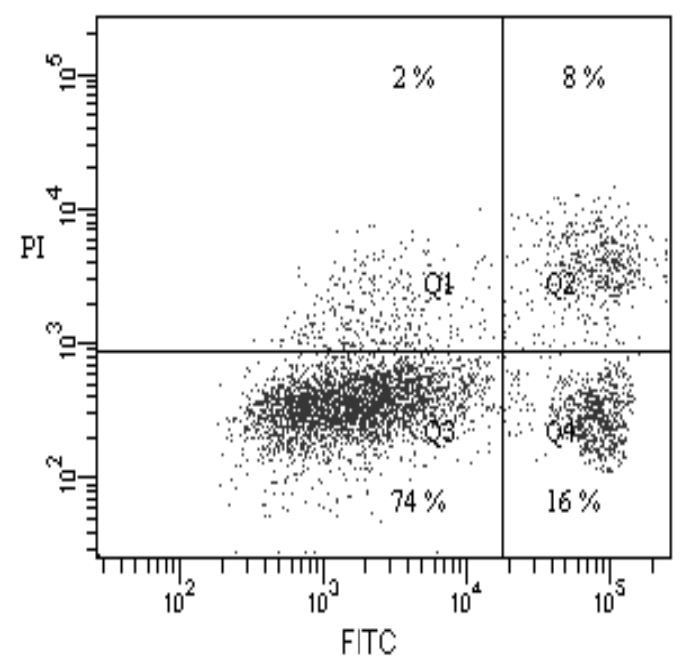

(B)

Figure 1. (A) The effect of recombinant IL-2 in different doses on the lymphocyte apoptosis (on the horizontal axis - the cytokine dose in $\mathrm{ng} / \mathrm{ml}$, on the vertical axis - the number of apoptosis lymphocytes in \%). (B) Analysis of apoptosis by FACS $\left(\mathrm{Q}_{2}\right.$ - population of dead cells, $\mathrm{Q}_{3}$ - population of live cells, $\mathrm{Q}_{4}$ - population of apoptotic cells) 


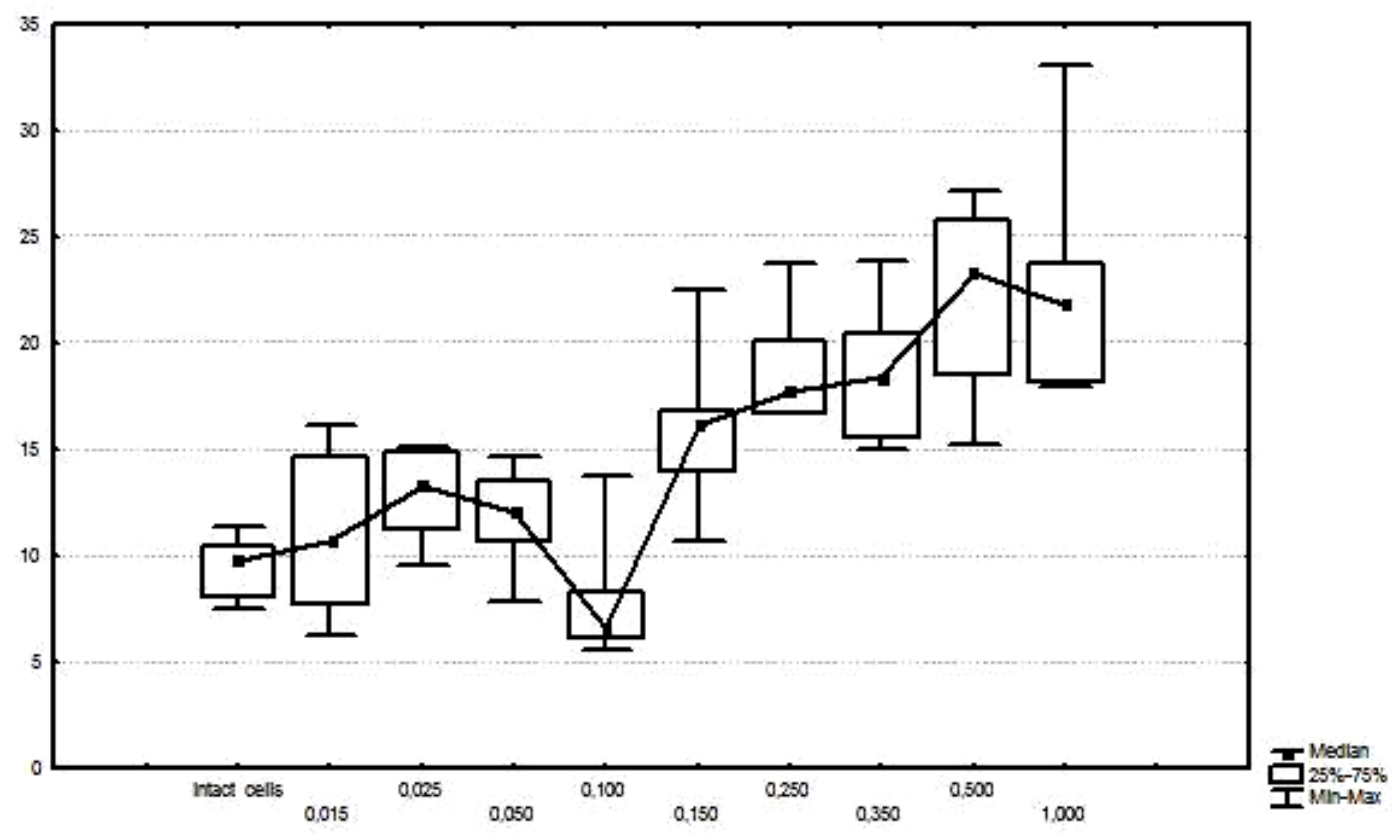

(A)

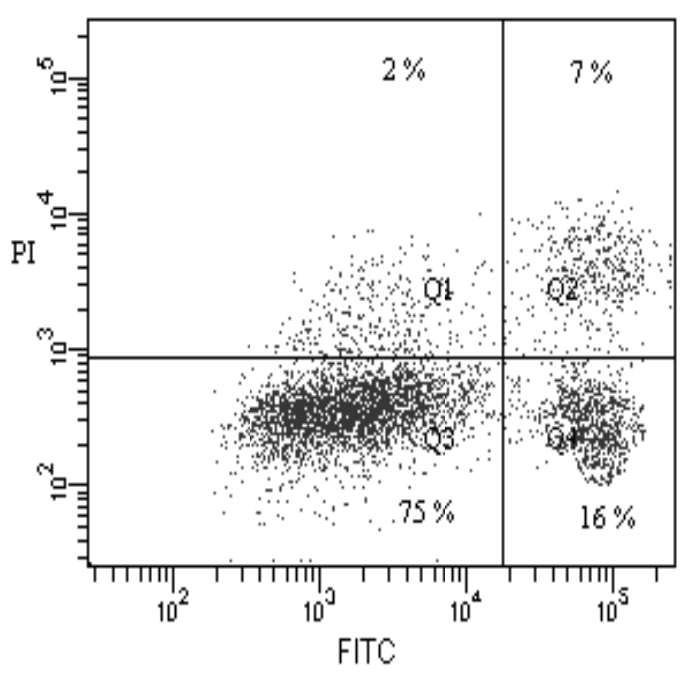

(B)

Figure 2. (A) The effect of recombinant IL-4 in different doses on the lymphocyte apoptosis (on the horizontal axis - the cytokine dose in $\mathrm{ng} / \mathrm{ml}$, on the vertical axis - the number of apoptosis lymphocytes in \%). (B) Analysis of apoptosis by FACS $\left(\mathrm{Q}_{2}\right.$ - population of dead cells, $\mathrm{Q}_{3}$ - population of live cells, $\mathrm{Q}_{4}$ - population of apoptotic cells) 

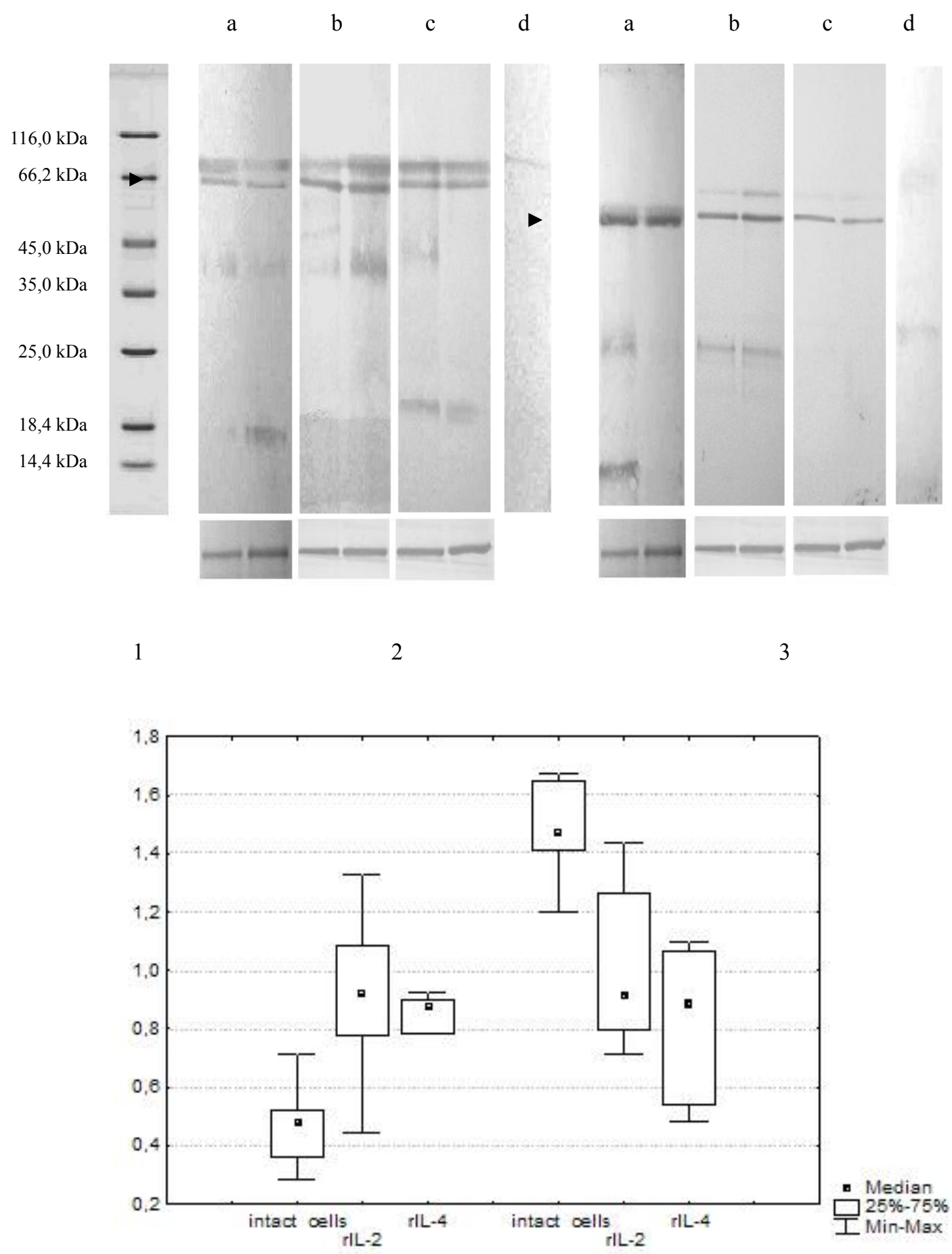

Figure 3. The level of transcription factors Rel A (P65) NF-kB and p53 in lymphocytes ( 1 - the proteins weight molecular marker, 2 - NF-kB, 3 - p53 (a - intact cell culture, b - cells cultured with rIL - 2 in the concentration of $0.10 \mathrm{ng} / \mathrm{ml}, \mathrm{c}$ - cells cultured with rIL-4 in the concentration of $0.15 \mathrm{ng} / \mathrm{ml}, \mathrm{d}$ - negative control; G3PDH glycero-3-phosphate dehydrogenase) 

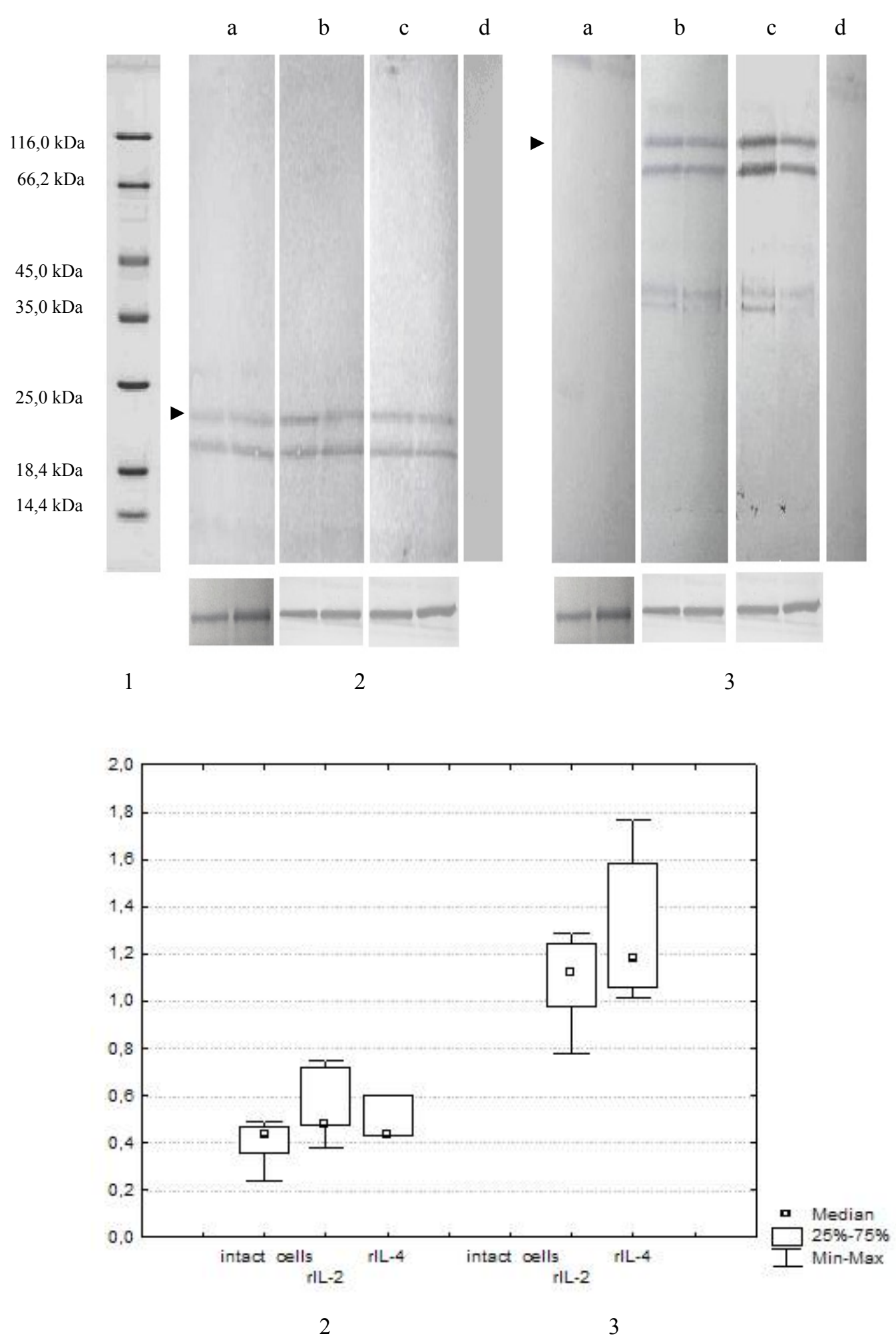

Figure 4 . The level of proteins $\mathrm{p} 21^{\mathrm{WAF} 1 / \mathrm{Cip} 1}$ and $\mathrm{pRb}$ in lymphocytes $(1$ - the proteins weight molecular marker, 2 $-\mathrm{p} 21^{\mathrm{WAF} 1 / \mathrm{Cip} 1}, 3-\mathrm{pRb}$ ( $\mathrm{a}$ - intact cell culture, $\mathrm{b}$ - cells cultured with rIL-2 in concentrations of $0.10 \mathrm{ng} / \mathrm{ml}, \mathrm{c}-$ cells cultured with rIL-4 in a concentration of $0.15 \mathrm{ng} / \mathrm{ml}$, d - negative control; G3PDH - glycero-3-phosphate dehydrogenase) 